\title{
Nafkah Madliyah Anak Pasca Perceraian: Studi Putusan Mahkamah Agung Republik Indonesia Nomor 608/K/AG/2003
}

\author{
Nuriel Amiriyyah \\ Fakultas Syariah UIN Maulana Malik Ibrahim Malang \\ amiriyyahnuriel@yahoo.co.id
}

\begin{abstract}
:
This article aims to describe the review of Islamic law on the obligations of a father who abandoned the maintenance of the child in the decision of the Supreme Court number 608/K/AG/2003 and describing a living madliyah children after divorce based on the protection of children's rights in Law Number 23 Year 2002 on the Protection of Children. The result showed that the duty of a father to meet child support does not become payable if the elapsed time, but it could be due to maintenance if there is a decision of the judge. This imposition on the grounds that the father in condition to be able to work deliberately remiss. Supreme Court Decision No. 608/K/AG/2003 does not conflict with Islamic law. Every parent has an obligation to be responsible for nurturing, nurture, educate, and protect children. Deliberateness of a father neglects the obligation to provide maintenance, so that children can not get their rights and suffer a loss, then it can be described as acts of negligence as regulated in Law Number 23 of 2002 on the Protection of Children.
\end{abstract}

Artikel ini bertujuan mendeskripsikan tinjauan hukum Islam terhadap kewajiban seorang ayah yang telah melalaikan nafkah terhadap anak dalam putusan Mahkamah Agung RI nomor 608/K/AG/2003 dan mendeskripsikan nafkah madliyah anak pasca perceraian ditinjau dari aspek perlindungan hak anak dalam Undang-Undang Nomor 23 Tahun 2002 tentang Perlindungan Anak. Hasil pembahasan menunjukkan bahwa kewajiban seorang ayah untuk memenuhi nafkah anak tidak menjadi hutang jika telah lewat masanya, namun nafkah tersebut dapat menjadi hutang jika ada keputusan hakim. Pembebanan ini dengan alasan bahwa ayah dalam kodisi mampu untuk bekerja sengaja melalaikan kewajibannya. Keputusan Mahkamah Agung RI Nomor: 608/K/AG/2003 tidak bertentangan dengan hukum Islam. Setiap orang tua memiliki kewajiban untuk bertanggung jawab untuk mengasuh, memelihara, mendidik, dan melindungi anak. Kesengajaan dari seorang ayah melalaikan kewajiban dalam memberikan nafkah, sehingga anak tidak dapat memperoleh haknya dan mengalami kerugian, maka hal tersebut dapat dikatakan sebagai tindakan penelantaran sebagaimana diatur dalam UndangUndang Nomor 23 tahun 2002 tentang Perlindungan Anak.

Kata Kunci: Nafkah Madliyah, Anak, Perceraian.

\section{Pendahuluan}

Allah SWT menciptakan manusia secara berpasang-pasangan untuk memperoleh keturunan dan beribadah kepada Allah SWT. Hasrat dasar manusia ini difasilitasi melalui institusi perkawinan. Menurut mazhab Syafi'iah, nikah dirumuskan dengan akad yang menjamin kepemilikan untuk bersetubuh dengan menggunakan lafal inkah atau tazwij atau turunan makna dari keduanya. Sedangkan menurut Ahmad Ghandur, nikah adalah akad yang menimbulkan kebolehan bergaul antara laki-laki dan perempuan dalam tuntutan naluri kemanusiaan dalam kehidupan dan menjadikan untuk kedua pihak secara 
timbal balik hak-hak dan kewajiban-kewajiban. ${ }^{1}$ Dalam Kompilasi Hukum Islam (KHI) pasal 2 dan 3 menyatakan bahwa perkawinan menurut hukum Islam adalah pernikahan, yaitu akad yang sangat kuat atau mitssaqan ghalidzan untuk mentaati perintah Allah dan melaksanakannya merupakan ibadah. Perkawinan bertujuan untuk mewujudkan kehidupan rumah tangga yang sakinah, mawaddah, dan rahmah. ${ }^{2}$

Dengan adanya ikatan perkawinan akan muncul hak dan kewajiban bagi seorang suami dan istri. Dalam pasal 80 ayat (4) Kompilasi Hukum Islam misalnya, seorang suami sesuai dengan penghasilannya menanggung : 1) Nafkah, kiswah dan tempat kediaman bagi isteri; 2) Biaya rumah tangga, biaya perawatan dan biaya pengobatan bagi isteri dan anak; 3) Biaya pendididkan bagi anak. ${ }^{3}$ Nafkah adalah sejumlah uang atau barang yang diberikan oleh seseorang untuk keperluan hidup orang lain, seperti istri, anak, keluarga dan sebagainya. ${ }^{4}$ Dalam Islam, persoalan nafkah mendapat perhatian. Sebagaimana firman Allah SWT dalam QS. at-Thalaq: 6: "Tempatkanlah mereka (para istri) di mana kamu bertempat tinggal menurut kemampuanmu dan janganlah kamu menyusahkan mereka untuk menyempitkan (hati) mereka. Dan jika mereka (istri-istri yang sudah ditalak) itu sedang hamil, maka berikanlah kepada mereka nafkahnya hingga mereka bersalin, kemudian jika mereka menyusukan (anak-anak) mu untukmu, maka berikanlah kepada mereka upahnya; dan musyawarahkanlah di antara kamu (segala sesuatu), dengan baik; dan jika kamu menemui kesulitan maka perempuan lain boleh menyusukan (anak itu) untuknya."

Dalam menjalani kehidupan rumah tangga, tidak menutup kemungkinan terjadi perselisihan dan pertengkaran antar suami istri. Jika tidak dapat diselesaikan dengan baik, bisa mengarah pada keretakan hubungan bahkan perceraian. Jika terjadi perceraian, hak dan kewajiban masing-masing pihak masih tetap ada. Dalam pasal 149 Kompilasi Hukum Islam dijelaskan bahwa bilamana perkawinan putus karena talak, maka bekas suami wajib: 1) Memberikan mut ah yang layak kepada bekas isterinya, baik berupa uang atau benda, kecuali bekas isteri tersebut qobla al dukhul; 2) Memberi nafkah, maskan dan kiswah kepada bekas isteri selama dalam iddah, kecuali bekas isteri telah di jatuhi talak ba'in atau nusyus dan dalam keadaan tidak hamil; 3) Melunasi mahar yang masih terhutang seluruhnya, dan separuh apabila qobla al-dukhul; 4) Memberikan biaya hadhanah untuk anak-anaknya yang belum mencapai umur 21 tahun. ${ }^{5}$ Akibat hukum perceraian lebih lanjut dijelaskan pada pasal 41 UndangUndang Nomor 1 Tahun 1974, sebagai berikut: 1) Baik ibu atau bapak tetap berkewajiban memelihara dan mendidik anak-anaknya, semata-mata berdasarkan kepentingan anak, bilamana ada perselisihan mengenai penguasaan anak-anak, Pengadilan memberi keputusan; 2) Bapak yang bertanggung jawab atas semua biaya pemeliharaan dan pendidikan yang diperlukan anak itu, bilamana bapak dalam kenyataannya tidak dapat memberi kewajiban tersebut Pengadilan dapat menentukan bahwa ibu ikut memikul biaya tersebut; 3) Pengadilan dapat mewajibkan kepada bekas suami untuk memberikan biaya penghidupan dan/atau menentukan sesuatu kewajiban bagi bekas isteri. ${ }^{6}$

Dalam perkara perceraian, khususnya cerai talak (cerai atas kehendak suami) memungkinkan bekas istri dapat menggugat terhadap bekas suami atas nafkah selama masa iddah, mut'ah, dan nafkah madliyah (nafkah lampau), yang mana nafkah-nafkah

\footnotetext{
${ }^{1}$ Mardani, Hukum Perkawinan Islam Di Dunia Islam Modern (Yogyakarta: Graha Ilmu, 2011), 4.

${ }^{2}$ Kompilasi Hukum Islam yang disebarluaskan melalui Instruksi Presiden No. 1 Tahun 1991

${ }^{3}$ Kompilasi Hukum Islam yang disebarluaskan melalui Instruksi Presiden No. 1 Tahun 1991

${ }^{4}$ Muhammad Bagir, Fiqih Praktis II: Menurut Al-Quran, As-Sunnah, dan Pendapat Para Ulama

(Bandung: Karisma, 2008), 136.

${ }^{5}$ Kompilasi Hukum Islam yang disebarluaskan melalui Instruksi Presiden No. 1 Tahun 1991

${ }^{6}$ Undang-Undang Nomor 1 Tahun 1974 tentang Perkawinan Lembar Negara No. 1 Tahun 1974

Jurisdictie: Jurnal Hukum dan Syariah Vol. 6 No. 1 Tahun 2015
} 
tersebut merupakan hak istri. Nafkah madliyah merupakan nafkah terhutang atas istri yang tidak dipenuhi oleh suami. Jumhur ulama berpendapat bahwa nafkah berubah menjadi hutang semenjak menjadi kewajiban dan suami menolak untuk melaksanakannya. Nafkah madliyah pada umumnya merupakan kewajiban seorang suami kepada istri yang telah dilalaikan. Dimana nafkah tersebut dapat berubah menjadi hutang sejak menjadi kewajiban dan suami menolak untuk melaksanakannya. Statusnya dapat menjadi hutang yang kuat kecuali dengan dibayarkan dan dengan adanya kerelaan dari istri, sehingga hutang nafkah tersebut dapat dianggap lunas. Kemudian muncul pertanyaan bagaimana jika seorang ayah yang melalaikan kewajiban nafkah kepada anak, apakah kemudian nafkah tersebut tidak menjadi hutang bagi sang ayah. Dalam putusan perkara perdata agama dalam tingkat kasasi oleh Mahkamah Agung RI Nomor: 608/K/AG/2003, menyatakan dalam amar putusannya gugatan istri terhadap nafkah lampau anak dinyatakan tidak dapat diterima. Mahkamah Agung berpendapat bahwa kewajiban seorang ayah memberikan nafkah kepada anaknya adalah lii intifa bukan lii tamlik, maka kelalaian seorang ayah yang tidak memberikan nafkah kepada anaknya (nafkah madliyah anak) tidak bisa digugat. ${ }^{7}$

Putusan Mahkamah Agung RI tersebut menunjukkan bahwa nafkah dari ayah yang diberikan untuk anak itu bersifat memberi manfaat atau untuk diambil manfaatnya oleh anak tersebut, bukan kemudian nafkah tersebut menjadi hak milik sepenuhnya bagi anak. Sehingga kelalaian seorang ayah yang tidak memberi nafkah kepada anaknya tidak dapat digugat. Sedangkan jika ditinjau dari aspek perlindungan terhadap menurut hukum Islam, anak memiliki hak untuk hidup, hak dalam kejelasan nasab, hak dalam pemberian nama yang baik, hak memperoleh ASI, hak dalam mendapatkan asuhan, perawatan dan pemeliharaan, hak dalam kepemilikan harta benda dan hak dalam memperoleh pengajaran. ${ }^{8}$ Sedangkan Pasal 4 Undang-Undang Nomor 23 Tahun 2002 tentang Perlindungan Anak menyebutkan bahwa setiap anak berhak untuk dapat hidup, tumbuh, berkembang, dan berpartisipasi secara wajar sesuai dengan harkat dan martabat kemanusiaan. Setiap anak berhak memperoleh pendidikan dan pengajaran dalam rangka pengembangan pribadinya dan tingkat kecerdasannya sesuai dengan minat dan bakatnya sebagaiama Pasal 9 ayat (1). Serta pasal 26 ayat 1 bahwa orang tua berkewajiban dan bertanggung jawab untuk mengasuh, memelihara, mendidik, dan melindungi anak. ${ }^{9}$

Dari penjelasan pasal-pasal di atas, seorang anak berhak untuk hidup, tumbuh, berkembang dan memperoleh pendidikan. Sedangkan orang tua memiliki kewajiban untuk mengasuh, memelihara, mendidik dan melindungi anak. Pasal-pasal tersebut mengandung konsekuensi bahwa orang tua seharusnya mampu untuk mengasuh dan mendidik anaknya bahkan untuk memenuhi hak anak seperti untuk memperoleh asuhan, perawatan, pemeliharaan, memperoleh pendidikan dan pengajaran yang layak adalah dengan memberikan biaya atau nafkah demi tercapainya hak-hak anak. Selanjutnya pada pasal 13 ayat 1 Undang-Undang Nomor 23 Tahun 2002 tentang Perlindungan Anak, bahwa setiap anak selama dalam pengasuhan orang tua, wali, atau pihak lain mana pun yang bertanggung jawab atas pengasuhan, berhak mendapat perlindungan dari perlakuan: diskriminasi, eksploitasi, baik ekonomi maupun seksual, penelantaran, kekejaman, kekerasan, dan penganiayaan, ketidakadilan dan perlakuan salah lainnya. Berdasarkan pasal tersebut bahwa seorang anak berhak untuk memperoleh perlindungan dari segala tindakan yang dapat merugikan anak baik dari segi moril maupun materil, termasuk diantaranya tindakan penelantaran. Maka muncul pertanyaan, bagaimana tinjauan hukum

\footnotetext{
${ }^{7}$ Putusan Mahkamah Agung RI Nomor 608/K/AG/2003

${ }^{8}$ Mufidah Cholil, Psikologi Keluarga Islam Berwawasan Gender (Malang: UIN-Malang Press, 2013), 273.

${ }^{9}$ Undang-undang No. 23 Tahun 2002, Lembaran Negara No. 109 Tahun 2002
}

Jurisdictie: Jurnal Hukum dan Syariah Vol. 6 No. 1 Tahun 2015 
Islam terhadap kewajiban seorang ayah yang telah melalaikan nafkah terhadap anak dalam putusan Mahkamah Agung RI nomor 608/K/AG/2003. Jika melihat latar belakang ayah yang sengaja melalaikan anaknya hingga pergi meninggalkan rumah, padahal ayah dalam kondisi mampu secara fisik dan mampu dalam keuangan untuk memberikan nafkah.

Sedangkan dalam hukum Islam, imam mazhab memiliki beberapa pandangan yang berbeda mengenai kewajiban seorang ayah yang telah melalaikan nafkah terhadap anak atau nafkah madliyah anak. Dimana menurut pendapat Syafi'iyah bahwa nafkah anak dapat menjadi hutang bagi ayah atas seizin dari hakim. Kemudian bagaimana nafkah madliyah anak pasca perceraian ditinjau dari aspek perlindungan hak anak dalam Undang-Undang Nomor 23 Tahun 2002 tentang Perlindungan Anak?. Jika selama ayah tidak memberikan nafkah kepada anak berakibat anak tersebut tidak dapat memperoleh hak-haknya dan mengalami kerugian baik moril maupun materil. Berdasakan urian di atas, artikel ini bertujuan mendeskripsikan tinjauan hukum Islam terhadap kewajiban seorang ayah yang telah melalaikan nafkah terhadap anak dalam putusan Mahkamah Agung RI nomor 608/K/AG/2003 dan mendeskripsikan nafkah madliyah anak pasca perceraian ditinjau dari aspek perlindungan hak anak dalam Undang-Undang Nomor 23 Tahun 2002 tentang Perlindungan Anak.

\section{Metode Penelitian}

Penelitian ini termasuk dalam jenis penelitian hukum normatif, ${ }^{10}$ dengan menggunakan pendekatan perundang-undangan (statute approach) dan pendekatan konseptual (conceptual approach). Pendekatan undang-undang dilakukan dengan menelaah semua peraturan perundang- undangan dan regulasi yang bersangkut paut dengan isu hukum yang sedang diteliti. ${ }^{11}$ Sedangkan pendekatan konseptual beranjak dari Pandangan-pandangan dan doktrin-doktrin yang berkembang dalam ilmu hukum. Pemahaman akan pandangan dan doktrin-doktrin tersebut dapat membangun sebuah argumentasi hukum dalam memecahkan isu yang dihadapi. ${ }^{12}$ Bahan hukum primer meliputi: al-Qur'an dan hadits, putusan Mahkamah Agung RI nomor 608/K/AG/2003, dan Undang-Undang Nomor 23 Tahun 2002 tentang Perlindungan Anak. ${ }^{13}$ Bahan hukum sekunder adalah bahan yang memberikan penjelasan mengenai bahan hukum primer. Bahan hukum sekunder meliputi beberapa literature seperti, buku-buku. Pengolahan bahan hukum dalam penelitian hukum normatif adalah dengan cara studi kepustakaan diuraikan kemudian dihubungkan antara bahan hukum satu dengan bahan hukum lainnya, terutama relasi antara unsur yang tercakup dalammasalah penelitian. Sehingga dipaparkan dalam bentuk penulisan yang sistematis guna menjawab permasalahan yang telah dirumuskan dalam penelitian ini.

\section{Hasil dan Pembahasan}

\section{Kewajiban Ayah Dalam Pemenuhan Nafkah Dalam Putusan Mahkamah Agung RI Nomor 608/K/AG/2003 Perspektif Hukum Islam}

Sebagaimana terlah disampaikan dalam latar belakang, perkawinan merupakan ikatan lahir batin antara laki-laki dan perempuan sebagai suami istri yang dilaksanakan melalui sebuah akad. Hal tersebut mengandung konsekuensi bahwa sejak terjadinya akad

\footnotetext{
${ }^{10}$ Soerjono Soekanto and Sri Mamudji, Penelitian Hukum Normatif: Suatu Tinjauan Singkat (Jakarta: RajaGrafindo Persada, 2006), 18.

11 Peter Mahmud Marzuki, Penelitian Hukum (Jakarta: Kencana, 2010), 93.

12 Marzuki, Penelitian Hukum, 95.

${ }^{13}$ Amiruddin and Zainal Asikin, Pengantar Metode Penelitian Hukum (Jakarta: RajaGrafindo Persada, 2012), 119.
}

Jurisdictie: Jurnal Hukum dan Syariah Vol. 6 No. 1 Tahun 2015 
perkawinan yang sah, maka seorang laki-laki dan perempuan sebagai suami istri memiliki hak dan kewajiban yang timbul setelah adanya akad perkawinan. Kewajiban tersebut meliputi kewajiban untuk saling menjaga, homat menghormati, saling mencintai, saling setia dan saling memberi bantuan baik lahir maupun batin. Kewajiban dari seorang istri adalah mengatur urusan rumah tangga dengan sebaik mungkin, merawat serta mendidik anaknya. Sedangkan suami memiliki kewajiban untuk melindungi isteri dan anaknya serta memberikan segala sesuatu keperluan hidup berumah tangga sesuai dengan kemampuannya. Apabila akad perkawinan telah sah dan berlaku, maka perkawinan tersebut akan memiliki kekuatan hukum dan dengan demikian akan menimbulkan hak serta kewajiban sebagai suami-istri. Dalam kajian hukum Islam, akad nikah yang sah menimbulkan hak dan kewajiban antara suami-istri. Diantaranya pihak istri berhak untuk mendapatkan nafkah dari pihak suami yang menikahinya. ${ }^{14}$

Adapun sebab-sebab yang menjadikan seorang suami wajib memberikan nafkah kepada istri yaitu: 1) Adanya ikatan perkawinan yang sah 2) Penyerahan diri istri kepada suami dan memungkinkannya bersenang-senang; 3) Pindah sesuai dengan yang diinginkan suami, kecuali jika berpergian yang menyakitkan atau tidak merasa aman atas diri dan hartanya. 4) Mereka bisa diajak bersenang-senang. Jika istri masih kecil, belum dapat untuk berhubungan, menurut ulama Malikiyah dan Syafi'iyah berpendapat tidak wajib nafkah, karena tidak secara sempurna untuk bersenang-senang. Sedangkan menurut ulama Hanafiyah berpendapat, jika suami menahan istri yang masih kecil dan tinggal bersama untuk bersenang-senang maka wajib memberi nafkah. ${ }^{15}$ Hak dapat diartikan wewenang atau kekuasaan yang secara etis seseorang dapat mengerjakan, memiliki, meninggalkan, mempergunakan atau menuntut sesuatu. Sedangkan kewajiban adalah suatu beban atau tanggungan yang bersifat kontraktual. Dengan kata lain kewajiban adalah sesuatu yang sepatutnya diberikan. Hak dan kewajiban dibagi menjadi tiga macam, yaitu: hak suami atas istri, hak istri atas suami dan hak bersama. ${ }^{16}$ Abdurrahman Ahmad dalam bukunya menjelaskan mengenai hak bersama suami dan istri menurut Islam, yaitu: suami istri, hendaknya saling menumbuhkan suasana mawaddah dan rahmah (ar-Rum: 21), hendaknya saling mempercayai dan memahami sifat masing-masing pasangannya (an-Nisa': 19 dan al-Hujuraat: 10), hendaknya menghiasi dengan pergaulan yang harmonis (an-Nisa': 19) dan hendaknya saling menasehati dalam kebaikan (Muttafaqun Alaih).

Menurut Undang-Undang Nomor 1 Tahun 1974 tentang Perkawinan, hak dan kewajiban suami istri adalah suami-isteri memikul kewajiban yang luhur untuk menegakkan rumah tangga yang menjadi sendi dasar susunan masyarakat. Hak dan kedudukan isteri adalah seimbang dengan hak dan kedudukan suami dalam kehidupan rumah tangga dan pergaulan hidup bersama dalam masyarakat. Suami isteri wajib saling cinta mencintai, hormat menghormati, setia dan memberi bantuan lahir bathin yang satu kepada yang lain. Suami wajib melindungi isterinya dan memberikan segala sesuatu keperluan hidup berumah tangga sesuai dengan kemampuannya dan isteri wajib mengatur urusan rumah-tangga sebaik-baiknya. Lebih lanjut kewajiban suami dan istri itu diatur dalam Kompilasi Hukum Islam buku I tentang Hukum Perkawinan. Kewajiban Suami sebagaimana diatur dalam Pasal 80 meliputi: a) Suami adalah pembimbing, terhadap istri dan rumah tangganya, akan tetap mengenai hal-hal urusan rumah tangga yang pentingpenting diputuskan oleh suami-istri bersama-sama; b) Suami wajib melindungi istrinya dan memberikan segala sesuatu keperluan hidup berumah tangga sesuai dengan

\footnotetext{
${ }^{14}$ Jaenal Aripin, Problematika Hukum Keluarga Islam Kontemporer (Jakarta: Prenada Media, 2004), 152.

${ }^{15}$ Abdul Aziz Muhammd Azzam and Abdul Wahhab Sayyed Hawwas, Fiqh Munakahat "Khitbah,

Nafkah Dan Talak” (Jakarta: Amzah, 2009), 214.

${ }^{16}$ Sayyid Sabiq, Fikih Sunnah, trans. Moh. Thalib, vol. 6 (Bandung: Alma’arif, 1987), 52.
} 
kemampuannya; c) Suami wajib memberikan pendidikan agama kepada istrinya dan member kesempatan belajar pengetahuan yang berguna dan bermanfaat bagi agama, nusa dan bangsa; d) Sesuai dengan penghasilannya, suami menanggung: nafkah, kiswah dan tempat kediaman bagi istri, biaya rumah tangga, biaya perawatan dan biaya pengobatan bagi istri dan anak, biaya pendidikan bagi anak; e) Kewajiban suami terhadap istrinya seperti tersebut pada ayat (4) diatas, mulai berlaku sesudah ada tamkin sempurna dari istrinya; f) Istri dapat membebaskan suaminya dari keawjiban terhadap dirinya sebagaimana tersebut pada ayat (4); g) Kewajiban suami sebagaimana dmaksud ayat (5) gugur apabila istri nusyuz

Sedangkan kewajiban Istri diatur dalam Pasal 83 KHI meliputi: a) Kewajiban utama bagi seorang istri ialah berbakti lahir dan batin kepada suami di dalam yang dibenarkan oleh Hukum Islam; b) Istri menyelenggarakan dan mengatur keperluan rumah tangga sehari-hari dengan sebaik-baiknya Pasal 80 ayat 4 Kompilasi Hukum Islam (KHI), menjelaskan bahwa sesuai dengan penghasilannya suami menanggung : 1) Nafkah, kiswah dan tempat kediaman bagi isteri; 2) Biaya rumah tangga, biaya perawatan dan biaya pengobatan bagi isteri dan anak; 3) Biaya pendididkan bagi anak. ${ }^{17}$ Dari penjelasan pasal tersebut bahwa seorang suami memiliki kewajiban untuk memberikan nafkah kepada istri dan anak-anaknya. Dimana kewajiban seorang suami (ayah) juga termasuk untuk memberikan biaya pendidikan bagi anak. Secara umum, seperti yang dijelaskan Muhammad Bagir dalam karyanya nafkah adalah sejumlah uang atau barang yang diberikan oleh seseorang untuk keperluan hidup orang lain, seperti istri, anak, keluarga dan sebagainya. ${ }^{18}$ Dalam kitab fiqih sunnah karangan Sayyid Sabiq, menjelaskan tentang kewajiban suami membelanjai istrinya oleh karena adanya ikatan perkawinan yang sah, seorang istri menjadi terikat semata-mata kepada suaminya. Sebaliknya bagi suami ia berkewajiban memenuhi kebutuhannya dan memberi belanja kepadanya, selama ikatan suami istri berjalan dan istri tidak durhaka atau kerena hal-hal lain yang menghalangi penerimaan belanja. Lebih lanjut dalam Kitab Al-Umm karangan Imam Syafi'i menjelaskan bahwasanya seseorang berkewajiban memberi nafkah kepada istrinya, baik si istri berkecukupan (kaya) ataupun membutuhkan (miskin), karena suami telah mengungkung istrinya untuk kesenangan istrinya secara khusus. ${ }^{19}$ Kewajiban suami dijelaskan dalam firman Allah SWT QS. Al-Baqarah: 233 :

"Dan kewajiban ayah memberi makan dan pakaian kepada para ibu dengan cara yang makruf”.

Dari ayat di atas dapat diketahui bahwa seorang suami memiliki kewajiban untuk menafkahi istrinya secara ma'ruf yang sesuai dengan ketentuan agama, sesuai dengan kemampuan, serta tidak berlebihan dan tidak berkekurangan. Menurut pandangan peneliti dari ayat tersebut, bahwa nafkah yang diberikan kepada istri haruslah diperoleh dengan cara yang baik dan diberikan secara baik pula. Dimana jumlah nafkah yang diberikan adalah sesuai dengan kemampuan suami serta dapat memenuhi kebutuhan rumah tangga. Dalam ayat lain tentang kewajiban menafkahi anak,

"Para ibu hendaklah menyusukan anak-anaknya selama dua tahun penuh, yaitu bagi yang ingin menyempurnakan penyusuan. Dan kewajiban ayah memberi makan dan pakaian kepada para ibu dengan cara yang makruf......”. (QS. Al-Baqarah: 233).

\footnotetext{
${ }^{17}$ Kompilasi Hukum Islam yang disebarluaskan melalui Instruksi Presiden No. 1 Tahun 1991

${ }^{18}$ Bagir, Fiqih Praktis II, 136.

${ }^{19}$ Muhammad bin Idris al-Syafi'i, Ringkasan Kitab Al-Umm Buku II, trans. Muhammad Yasir Abd. Muthalib (Jakarta: Pustaka Azzam, 2007), 430.
}

Jurisdictie: Jurnal Hukum dan Syariah Vol. 6 No. 1 Tahun 2015 
Dari ayat tersebut bahwa seorang ayah memiliki kewajiban untuk menafkahi anak sebab kelahirannya, begitu pula dengan pemberian nafkah terhadap ibu yang telah melahirkan, menyusui, merawat dan membesarkan anaknya. Menurut Wahbah AzZuhaili dalam karyanya, terdapat syarat-syarat wajibnya nafkah atas anak yaitu, pertama; orang tua tergolong mampu untuk memberi nafkah atau mampu bekerja, kedua; anakanak dalam keadaan miskin tidak memiliki harta atau tidak mampu bekerja, ketiga; orang yang bisa dianggap lemah atau tidak mampu bekerja. ${ }^{20}$ Penulis berpendapat mengenai syarat-syarat wajibnya nafkah atas anak tersebut diatas, sebagai berikut: Pertama, orang tua mampu untuk untuk memberi nafkah dan mampu untuk bekerja. Artinya bahwa orang tua dalam keadaan sehat, tidak sakit dan tidak memiliki cacat badan yang dapat menghalangi pemberian nafkah; Kedua, anak-anak dalam keadaan miskin tidak memiliki harta atau tidak mampu bekerja. Artinya bahwa meskipun anak sudah dewasa ataupun sudah menikah, namun apabila anak dalam keadaan miskin atau karena kondisi fisik anak yang tidak sehat, seperti dalam keadaan sakit, anak memiliki cacat badan, sehingga tidak mampu untuk bekerja, maka orang tua wajib untuk memberikan nafkah kepada anaknya tersebut.

Ketiga, orang yang dianggap lemah dan tidak mampu bekerja. Artinya bahwa orang yang dianggap lemah dan tidak mampu bekerja adalah seperti anak kecil atau perempuan. Dimana mereka dianggap lemah dan tidak cakap, jika harus bekerja, terutama untuk mengerjakan pekerjaan yang berat atau pekerjaan yang membutuhkan tenaga dan waktu yang tidak sedikit. Sehingga orang tua wajib untuk memberikan nafkah kepada orangorang tersebut. Merujuk kepada pembahasan sebelumnya, terlepas dari tujuan utama perkawinan yaitu untuk membentuk keluarga yang bahagia dan kekal. Apabila kondisi rumah tangga sudah tidak dapat dipertahankan lagi, maka solusi terakhir adalah melalui jalan perceraian. Perceraian secara yuridis adalah putusnya hubungan perkawinan. Islam sendiri tidak melarang adanya perceraian, apabila kondisi rumah tangga yang sudah tidak memungkinkan untuk disatukan kembali dan tidak dapat dipertahankan, serta menimbulkan banyak kemudharatan, maka perceraian boleh dilakukan. Setelah putusnya hubungan perkawinan antara suami dan istri, tidak kemudian antara bekas suami dan bekas istri terlepas dari tanggung jawabnya. Bekas suami tetap memiliki kewajiban untuk memberikan nafkah selama masa iddah istri dan memberikan nafkah kepada anak hingga anak itu dewasa dan mandiri. Dalam pasal 41 Undang-Undang Nomor 1 Tahun 1974, menjelaskan akibat hukum perceraian yaitu: 1) Baik ibu atau bapak tetap berkewajiban memelihara dan mendidik anakanaknya, semata-mata berdasarkan kepentingan anak, bilamana ada perselisihan mengenai penguasaan anak-anak, Pengadilan memberi keputusan; 2) Bapak yang bertanggung jawab atas semua biaya pemeliharaan dan pendidikan yang diperlukan anak itu, bilamana bapak dalam kenyataannya tidak dapat memberi kewajiban tersebut Pengadilan dapat menentukan bahwa ibu ikut memikul biaya tersebut; 3) Pengadilan dapat mewajibkan kepada bekas suami untuk memberikan biaya penghidupan dan/atau menentukan sesuatu kewajiban bagi bekas isteri. ${ }^{21}$

Dari penjelasan pasal diatas, bahwa orang tua tetap memiliki kewajiban untuk, memelihara, merawat dan mendidik anaknya meskipun hubungan perkawinan antara kedua orang tua telah putus. Selain itu ayah bertanggung jawab secara penuh terhadap semua biaya pemeliharaan dan pendidikan anak, namun apabila dalam kenyataannya, ayah tidak mampun untung menanggung keseluruhan biaya anak, maka pengadilan dapat menetapkan ibu ikut membantu ayah dalam memenuhi kebutuhan anak, Lebih lanjut pasal 149 Kompilasi Hukum Islam (KHI) menjelaskan bilamana perkawinan putus karena

\footnotetext{
${ }^{20}$ Wahbah Az-Zuhaili, Fiqh Islam Wa Adillatuhu, trans. Abdul Hayyie al-Kattani, vol. 10 (Jakarta: Gema Insani Press, 2011), 137-38.

${ }^{21}$ Undang-Undang Nomor 1 Tahun 1974 tetang Perkawinan Lembaran Negara No. 1 Tahun 1974
}

Jurisdictie: Jurnal Hukum dan Syariah Vol. 6 No. 1 Tahun 2015 
talak, maka bekas suami wajib: 1. Memberikan mut ah yang layak kepada bekas isterinya, baik berupa uang atau benda, kecuali bekas isteri tersebut qobla al dukhul; 2) Memberi nafkah, maskan dan kiswah kepada bekas isteri selama dalam iddah, kecuali bekas isteri telah di jatuhi talak ba'in atau nusyus dan dalam keadaan tidak hamil; 3) Melunasi mahar yang masih terhutang seluruhnya, dan separoh apabila qobla al dukhul; 4) Memberikan biaya hadhanah untuk anak-anaknya yang belum mencapai umur 21 tahun. ${ }^{22}$ Dari penjelasan undang-undang perkawinan dan Kompilasi Hukum Islam tersebut, peneliti menyimpulkan bahwasanya perceraian menimbulkan akibat hukum tidak hanya terhadap bekas suami dan bekas istri melainkan juga berakibat hukum pada anak. Dimana ayah tetap berkewajiban memberikan nafkah kepada anak hingga anak tersebut dewasa dan mandiri. Bila terjadi perceraian atas inisiatif suami berdasarkan pasal tersebut, maka bekas isteri berhak mendapatkan nafkah lahir dari suami yaitu nafkah iddah dan mut'ah. Selain itu hak istri lainnya adalah nafkah madliyah. Nafkah madliyah memang secara tertulis tidak diatur dalam undangundang atau pun peraturan lainnya, namun nafkah madliyah merupakan hak istri yang harus dipenuhi oleh suami. Nafkah madliyah yang secara umum diartikan sebagai nafkah lampau atau nafkah terhutang. Istilah nafkah madliyah sering digunakan dalam lingkup pengadilan agama sebagai salah satu hak istri yang dapat digugat.

Menurut jumhur ulama dalam kitab fikih sunnah, berpendapat bahwa nafkah berubah menjadi hutang semenjak menjadi kewajiban dan suami menolak untuk melaksanakannya. Apabila telah berubah menjadi hutang, maka statusnya menjadi hutang yang kuat, tidak bisa gugur kecuali dengan membayarnya atau dengan pembebasan seperti hutang yang lainnya. ${ }^{23}$ Hutang nafkah tersebut tidak dianggap gugur dengan kematian suami atau istri, tidak pula dengan perceraian yang terjadi setelah itu. Oleh karena itu, ia tetap menjadi hak mutlak si istri, sejumlah yang terhutang oleh suami selama masih berlangsungnya hubungan perkawinan antara mereka berdua. Demikian pula jika si suami meninggal dunia, maka hutang tersebut harus dibayarkan kepada istrinya, sebelum harta peninggalannya dibagi kepada para ahli waris. ${ }^{24}$

Sehingga nafkah madliyah atau nafkah terhutang yang menjadi hak istri tersebut dapat gugur, apabila istri secara sukarela dan tanpa paksaan menggugurkan hutang tersebut atas suaminya, dengan demikian nafkah terhutang dapat dianggap telah lunas. Lantas bagaimana dengan kewajiban seorang ayah yang telah melalaikan nafkah terhadap anak?, apakah nafkah anak yang telah dilalaikan dapat dianggap hutang bagi ayah yang harus dibayarkan?. Pada putusan Mahkamah Agung RI nomor 608/K/AG/2003, yang putus pada tanggal 23 Maret 2005, putusan tersebut merupakan putusan perkara perdata agama dalam tingkat kasasi. Dimana istri sebagai termohon/penggugat rekonvensi/pembanding/pemohon kasasi menggugat nafkah madliyah anak atau nafkah lampau anak, sebagai berikut:

\begin{abstract}
Bahwa sejak Januari 2000 sampai sekarang Tergugat Rekonvensi telah melalaikan kewajibannya sebagai seorang ayah yang baik, sehingga anak Penggugat Rekonvensi dan Tergugat Rekonvensi yang bernama --------berusia 14 tahun sekarang tinggal bersama Penggugat Rekonvensi, oleh karenanya pemeliharaan dan pengasuhan anak tersebut harus tetap bersama Penggugat Rekonvensi. ${ }^{25}$
\end{abstract}

\footnotetext{
${ }^{22}$ Kompilasi Hukum Islam yang disebarluaskan melalui Instruksi Presiden No. 1 Tahun 1991

${ }^{23}$ Sabiq, Fikih Sunnah, 6:79.

${ }^{24}$ Bagir, Fiqih Praktis II, 139.

${ }^{25}$ Putusan Mahkamah Agung RI Nomor 608/K/AG/2003

Jurisdictie: Jurnal Hukum dan Syariah Vol. 6 No. 1 Tahun 2015
} 
Bahwa berdasarkan hal-hal tersebut di atas, Termohon/Penggugat Rekonvensi memohon kepada Pengadilan Agama Buntok agar memutuskan sebagai berikut:

Menghukum Tergugat Rekonvensi untuk membayar nafkah anak dari hasil perkawinan Penggugat Rekonvensi dengan Tergugat Rekonvensi yang terhutang sebesar Rp. 33.600.000,- (tiga puluh tiga juta enam ratus ribu rupiah) kepada Penggugar Rekonvensi segera setelah putusan diucapkan. ${ }^{26}$

Namun dalam putusan Pengadilan Agama Buntok yang telah menjatuhkan putusan pada tanggal 5 November 2002, dalam rekonvensi menyatakan gugatan Penggugat Rekonvensi tidak dapat diterima. Kemudian putusan tersebut dalam tingkat banding atas permohonan Termohon telah diperbaiki oleh Pengadilan Tinggi Agama Palangkaraya dengan putusan tanggal 5 Juni 2003, dalam amar putusannya menyatakan gugatan Penggugat Rekonvensi termasuk didalamnya gugatan atas nafkah madliyah anak tidak dapat diterima. Bahwa setelah itu Termohon/Pembanding mengajukan permohonan Kasasi pada tanggal 11 Agustus 2003. Dimana alasan-alasan yang diajukan oleh Pemohon Kasasi dalam memori kasasinya mengenai nafkah madliyah anak sebagai berikut:

Bahwa Pemohon Kasasi dan ------- mempunyai hak atas nafkah terhutang. Dengan demikian pertimbangan dan putusan Pengadilan Tinggi Agama Palangkaraya yang tidak mempertimbangkan dan menyatakan masalah nafkah terhutang Temohon Kasasi kepada Pemohon Kasasi dan --------- tidak dapat diterima, maka berdasarkan ketentuan-ketentuan tersebut di atas Pengadilan Tinggi Agama Palangkaraya telah salah menerapkan dan melanggar hukum yang berlaku. ${ }^{27}$

Kemudian atas alasan dalam memori kasasi mengenai gugatan nafkah terhutang anak tersebut Mahkamah Agung RI berpendapat :

Bahwa kewajiban seorang ayah memberikan nafkah kepada anaknya adalah lii intifa bukan lii tamlik, maka kelalaian seorang ayah yang tidak memberikan nafkah kepada anaknya (nafkah madliyah anak) tidak bisa digugat. $^{28}$

Sehingga dalam amar putusan oleh Mahkamah Agung yang putus pada tanggal 23 Maret 2005, menyatakan menolak gugatan Penggugat Rekonvensi/ Pembanding/ Pemohon Kasasi atas nafkah madliyah anak. Berdasarkan alasan Mahkamah Agung atas penolakan terhadap gugatan nafkah madliyah anak tersebut diatas, peneliti memaparkan analisisnya mengenai nafkah madliyah anak, sebagai berikut : Pertama, apabila selama kurun waktu ayah tidak memberikan nafkah kepada anak, namun anak telah memperoleh nafkah dari ibu dan hak-haknya telah terpenuhi. Seperti pemenuhan hak-hak anak dalam hal untuk hidup, memperoleh pendidikan, tumbuh, berkembang, mendapatkan asuhan, pemeliharaan, dan perlindungan dari orang tua, meskipun anak hanya mendapatkannya dari ibunya saja. Dalam kenyataannya anak tetap bisa bersekolah, anak tetap bisa tumbuh dan berkembang, anak tetap bisa makan, minum, bertempat tinggal ditempat yang layak dan memperoleh perlindungan dari ibu, meskipun tidak mendapatkan biaya dari ayah. Maka nafkah yang telah dilalaikan oleh ayah terhadap anaknya tersebut dapat dinyatakan gugur. Hal ini berbeda dengan nafkah terhutang suami atas istri. Dimana nafkah terhutang tersebut statusnya menjadi hutang yang kuat, tidak dapat dianggap gugur meskipun

\footnotetext{
${ }^{26}$ Putusan Mahkamah Agung RI Nomor 608/K/AG/2003

${ }^{27}$ Putusan Mahkamah Agung RI Nomor 608/K/AG/2003

${ }^{28}$ Putusan Mahkamah Agung RI Nomor 608/K/AG/2003
} 
dengan kematian suami atau telah putusnya hubungan perkawinan, karena nafkah tersebut tetap menjadi hak mutlak si istri. Kecuali suami telah membayarnya atau istri secara sukarela dan tanpa paksaan, membebaskan hutang atas suaminya, maka hutang tersebut dapat dinyatakan lunas.

Kedua, kewajiban ayah memberikan nafkah kepada anaknya adalah lii intifa bukan lii tamlik. Artinya bahwa kewajiban ayah memberi nafkah kepada anak adalah bersifat memberi manfaat dan untuk diambil manfaatnya oleh anak tersebut, bukan kemudian nafkah oleh ayah yang diberikan kepada anak menjadi hak kepemilikan yang sepenuhnya menjadi milik si anak tersebut. Manfaat dari nafkah yang diperoleh anak dari ayahnya, dapat diambil manfatnya, misalkan untuk sekolah atau pemenuhan hak-hak anak lainnya. Hal itu berbeda dengan sifat nafkah yang diberikan suami kepada istri, karena sifatnya adalah kepemilikan. Dimana nafkah yang diberikan suami menjadi hak milik yang dapat langsung diberikan kepada istri untuk memenuhi kebutuhan istri sehari-hari. Namun, jika melihat dalam hukum Islam, kalangan imam mazhab memiliki pendapat yang berbeda tentang kewajiban seorang ayah yang telah melalaikan nafkah terhadap anak. Berikut peneliti akan memaparkan mengenai perbedaan pendapat dikalangan imam mazhab sebagai berikut ${ }^{29}$ : 1) Mazhab Hanafiyah Nafkah anak dalam mazhab Hanafiyah tidak menjadi hutang bagi sang ayah, baik ditetapkan oleh hakim maupun tidak. Berbeda dengan nafkah istri yang bisa berubah menjadi hutang atas suaminya jika sudah ditentukan oleh hakim atau dengan saling rela; 2) Mazhab Syafi'iyyah Ulama Syafi'iyyah berpendapat bahwa nafkah untuk anak itu tidak lantas menjadi hutang bagi sang ayah, kecuali ditentukan oleh hakim atau mendapat izin untuk berhutang. Sebab ayah sedang tidak dirumah atau sengaja tidak mau memberi nafkah. 3) Fuqaha Menurut para fuqaha', nafkah anak gugur dengan lewatnya masa tanpa diambil dan tanpa berhutang karena nafkah itu wajib atas ayah untuk memenuhi kebutuhan si anak, Jika masanya sudah lewat maka kebutuhan itu sudah tidak ada lagi sehingga nafkahnya juga gugur. Berdasarkan pendapat imam mazhab tersebut diatas, dapat disimpulkan bahwa menurut mazhad Hanafiyah dan para fuqaha menyatakan bahwa nafkah anak gugur karena lewatnya masa dan tidak dapat disebut hutang, karena kewajiban ayah menafkahi anak adalah untuk memenuhi kebutuhan. Jika kebutuhan itu sudah tidak ada dengan lewatnya masa maka nafkah tersebut telah gugur. Sedangkan menurut ulama Syafi'iyyah yang menyatakan bahwa nafkah anak tidak menjadi hutang bagi ayah dan gugurlah nafkah itu jika telah lewat masanya, namun nafkah tersebut dapat menjadi hutang jika berdasarkan ketentuan hakim, dengan alasan sang ayah yang tidak berada di rumah dan ayah sengaja tidak memberikan nafkah. Jika merujuk kembali pada putusan Mahkamah Agung RI nomor 608/K/AG/2003, dimana putusan ini dijadikan sebagai yurisprudensi oleh hakimhakim selanjutnya terhadap perkara yang sama mengenai nafkah madliyah anak.

Dalam putusan Mahkamah Agung Agung RI nomor 608/K/AG/2003 tersebut memiliki 3 kaidah hukum, yaitu: 1. Gugatan rekonvensi yang diajukan oleh kuasa Termohon dalam perkara cerai talak yang melampai batas kewenangan yang diberikan kepadanya, sebatas mengenai akibat perceraian, dapat dikabulkan secara ex officio. 2. Kewajiban seorang ayah memberikan nafkah kepada anaknya adalah lilintifa' bukan litamlik, maka kelalaian seorang ayah yang tidak memberikan nafkah kepada anaknya (nafkah madliyah anak) tidak bisa digugat 3. Jumlah nilai mut'ah, nafkah, maskan dan kiswah selama masa iddah serta nafkah anak harus memenuhi kebutuhan minimum, berdasarkan kepatutan dan rasa keadilan sesuai dengan ketentuan KHI dan perundangundangan yang berlaku. Namun yang menjadi fokus pembahasan adalah kaidah hukum mengenai kewajiban seorang ayah yang telah melalaikan nafkah terhadap anak atau

\footnotetext{
${ }^{29}$ Az-Zuhaili, Fiqh Islam Wa Adillatuhu, 10:142.

Jurisdictie: Jurnal Hukum dan Syariah Vol. 6 No. 1 Tahun 2015
} 
nafkah madliyah (lampau) anak yang telah dilalaikan oleh ayah. Menurut Kansil dalam bukunya, yurisprudensi adalah keputusan hakim yang berisikan suatu peraturan sendiri berdasarkan wewenang yang diberikan menjadi dasar keputusan hakim yang lainnya atau kemudian untuk mengadili perkara yang serupa dan keputusan hakim tersebut menjadi sumber hukum bagi pengadilan. ${ }^{30}$

Artinya bahwa yurisprudensi merupakan sumber hukum dan dapat dijadikan dasar keputusan bagi hakim-hakim selanjutnya dalam memutus suatu perkara yang sama. Namun yurisprudensi tidak mutlak harus diikuti oleh hakim-hakim berikutnya terhadap permasalahan yang sama, karena hakim memiliki hak ex-officio. Hak ex officio sebagaimana dijelaskan dalam kamus hukum, adalah karena jabatan. ${ }^{31}$ Sehingga hak ex officio merupakan hak hakim karena jabatannya, dan hakim memiliki kewenangan untuk memutus suatu perkara berdasarkan pertimbangan dan pemikirannya. Termasuk dalam hal memutus nafkah madliyah anak. Berdasarkan keterangan di atas peneliti menyimpulkan bahwa menurut kalangan Syafi'iyah nafkah anak menjadi gugur apabila telah lewat masanya dan waktu itu anak tidak sedang membutuhkan nafkah dari ayah, dimana nafkah dapat ia peroleh baik dari usahanya sendiri maupun mendapatkan nafkah dari ibunya. Namun jika dalam kurun waktu selama ayah tidak memberikan nafkah kepada anak, sedangkan waktu itu anak dalam keadaan membutuhkan nafkah dan ibu tidak dapat memberikan nafkah kepada anak, dikarenakan alasan-alasan seperti tidak mampu bekerja atau dalam kondisi sakit yang menjadikan terhalangnya pemberian nafkah, sehingga anak dan ibu harus berhutang untuk memenuhi kebutuhan sehari-hari, maka hakim dapat menetapkan nafkah madliyah atau nafkah lampau anak tersebut sebagai hutang yang harus dibayarkan oleh ayah. Maka berdasarkan pendapat kalangan Syafi'iyah tersebut diatas mengenai kewajiban seorang ayah yang telah melalaikan nafkah terhadap anak atau nafkah madliyah anak, dapat digunakan oleh hakim sebagai dasar untuk memutus masalah nafkah madliyah anak. Peneliti menyimpulkan beberapa alasan yang melatar belakangi nafkah madliyah anak dapat dianggap sebagai hutang bagi ayah, yaitu apabila: 1. Ayah dalam kondisi mampu untuk bekerja, sehat secara fisik dan mampu dalam segi keuangan 2. Ayah pergi meninggalkan rumah dan sengaja melalaikan anaknya 3. Anak dalam kondisi membutuhkan nafkah dari ayah untuk memenuhi kebutuhannya sehari-hari 4. Ibu dalam kondisi tidak mampu bekerja, seperti dalam keadaan sakit, atau memiliki cacat tubuh yang sehingga menghalangi pemberian nafkah kepada anak.

\section{Nafkah madliyah anak pasca perceraian ditinjau dari aspek perlindungan hak anak dalam Undang-Undang Nomor 23 Tahun 2002 Tentang Perlindungan Anak}

Nafkah anak merupakan kewajiban seorang ayah setelah adanya ikatan perkawinan yang sah. Sebagaimana diatur dalam pasal 80 ayat 4 Kompilasi Hukum Islam (KHI). Pemenuhan nafkah terhadap anak berkaitan erat dengan terjaminnya hak-hak dasar mereka. Misalnya hak anak untuk hidup, hak anak dalam mendapatkan asuhan, perawatan dan pemeliharaan, hak anak dalam kepemilikan harta benda, dan hak anak dalam memperoleh pengajaran. ${ }^{32}$ Dari penjelasan diatas, artinya bahwa Islam melalui firman Allah dalam al-Qur'an, sangat melindungi dan menjaga dengan baik hak-hak anak. Karena anak merupakan amanah dari Allah yang diberikan kepada orang tua untuk dijaga, diasuh, dirawat dan dilindungi dengan baik, sehingga diharapkan anak akan tumbuh menjadi sosok yang memiliki kepribadian yang sesuai dengan ajaran Islam. Anak dalam tumbuh kembangnya memiliki beberapa kebutuhan yang menjadi hak anak. Dimana

\footnotetext{
${ }^{30}$ C.S.T. Kansil, Pengantar Ilmu Hukum Dan Tata Hukum Indonesia (Jakarta: Balai Pustaka, 1989), 49.

${ }^{31}$ Sudarsono, Kamus Hukum (Jakarta: Rineka Cipta, 1992), 141.

${ }^{32}$ Cholil, Psikologi Keluarga Islam Berwawasan Gender, 273-280.
} 
kebutuhan tersebut harus dapat ia peroleh, baik dari orang tua, keluarga, masyarakat, maupun negara. Lebih lanjut Ali Qaimi, menjelaskan berbagai kebutuhan anak, meliputi: 1) Kebutuhan hidup jasmaniah. Mencakup makan, minum, tidur, istiraht, pakaian, bermain dan beraktivitas, kesehatan, tempat tinggal, serta keahlian dan keterampilan; 2) Kebutuhan emosional. Mencakup penerimaan di tengah keluarga, kasih sayang, penghormatan dan perhatian, penghargaan dan pujian, belasungkawa dan perasaan sehati, pengawasan, menangis, serta perasaan riang dan gembira; 3) Kebutuhan ruhani (jiwa). Mencakup dukungan, perasaan aman, keberhasilan, kebanggaan, harga diri dan dan kepercayaan diri; 4) Kebutuhan social. Mencakup saling kebergantungan, pergaulan dan persahabatan, peran dalam kehidupan social, panutan dan idola, peraturan, tata tertib, dan pendidikan, serta sopan santun dan akhlak; 5) Kebutuhan akan nilai-nilai luhur semasa pertumbuhan. Mencakup pengenalan diri, ilmu pengetahuan, tujuan hidup, berdoa dan memuji, kebebasan, dan kemerdekaan, pertumbuhan dan kesempurnaan, serta pertahanan dan pembelaan diri. ${ }^{33}$

Kebutuhan-kebutuhan tersebut diatas, perlu untuk diperoleh anak untuk menunjang tumbuh kembang dan pembentukan karakter anak. Dimana hak-hak anak tersebut sangat perlu untuk dilindungi, baik perlindungan hak tersebut oleh orang tua, keluarga, masyarakat maupun negara. Maidin Gultom dalam karyanya menjelaskan perlindungan anak adalah segala usaha yang dilakukan untuk menciptakan kondisi agar setiap anak dapat melaksanakan hak dan kewajibannya demi perkembangan dan pertumbuhan anak secara wajar baik fisik, mental dan social. Perlindungan anak merupakan perwujudan adanya keadilan dalam suatu masyarakat. ${ }^{34}$ Undang-Undang Nomor 23 Tahun 2002 tentang Perlindungan Anak merupakan peraturan yang mengatur segala aspek mengenai anak yang meliputi hak, kewajiban dan perlindungan hukum terhadap anak. Tujuan dari perlindungan anak berdasarkan pasal 3 Undang-Undang Nomor 23 Tahun 2002 adalah untuk menjamin terpenuhinya hak-hak anak agar dapat hidup, tumbuh, berkembang, dan berpartisipasi secara optimal sesuai dengan harkat dan martabat kemanusiaan, serta mendapat perlindungan dari kekerasan dan diskriminasi, demi terwujudnya anak Indonesia yang berkualitas, berakhlak mulia, dan sejahtera.

Dimana dalam pasal-pasalnya menjelaskan hak-hak anak meliputi: 1. Hak untuk dapat hidup, tumbuh, berkembang, dan berpartisipasi secara wajar sesuai dengan harkat dan martabat kemanusiaan, serta mendapat perlindungan dari kekerasan dan diskriminasi. 2. Hak atas nama sebagai identitas diri dan status kewarganegaraan. 3. Hak untuk beribadah menurut agamanya, berpikir, dan berekspresi 4. Hak untuk mengetahui orang tuanya, dibesarkan, dan diasuh oleh orang tuanya sendiri. 5. Hak memperoleh pelayanan kesehatan dan jaminan sosial sesuai dengan kebutuhan fisik, mental, spiritual, dan sosial. 6. Hak memperoleh pendidikan dan pengajaran dan bagi anak yang cacat berhak memperoleh pendidikan luar biasa. 7. Hak untuk didengar pendapatnya, menerima, mencari, dan memberikan informasi 8. Hak untuk beristirahat dan memanfaatkan waktu luang, bergaul dengan anak yang sebaya dan anak yang cacat berhak memperoleh rehabilitasi, bantuan sosial, dan pemeliharaan taraf kesejahteraan sosial. 9. Hak mendapat perlindungan dari perlakuan: diskriminasi, eksploitasi, penelantaran, kekejaman, kekerasan, penganiayaan, ketidak adilan dan perlakuan salah lainnya. 10. Hak untuk diasuh oleh orang tuanya sendiri 11. Hak untuk memperoleh perlindungan dari penyalahgunaan dalam kegiatan politik, pelibatan dalam sengketa bersenjata, pelibatan

\footnotetext{
${ }^{33}$ Ali Qaimi, Menggapai Langit Masa Depan Anak, trans. Muhammad Jawad Bafaqih (Bogor: Cahaya, 2002), 106-107.

${ }^{34}$ Maidin Gultom, Perlindungan Hukum Terhadap Anak dan Perempuan (Bandung: Refika Aditama, 2012), 33.
}

Jurisdictie: Jurnal Hukum dan Syariah Vol. 6 No. 1 Tahun 2015 
dalam kerusuhan social, pelibatan dalam peristiwa yang mengandung unsur kekerasan dan pelibatan dalam peperangan. 12. Hak memperoleh perlindungan dari sasaran penganiayaan, penyiksaan, atau penjatuhan hukuman yang tidak manusiawi. 13. Hak untuk memperoleh kebebasan sesuai dengan hukum. 14. Anak yang dirampas kebebasannya berhak untuk mendapatkan perlakuan secara manusiawi dan penempatannya dipisahkan dari orang dewasa, memperoleh bantuan hukum atau bantuan lainnya secara efektif dalam setiap tahapan upaya hukum yang berlaku; dan membela diri dan memperoleh keadilan di depan pengadilan anak yang objektif dan tidak memihak 15 . Anak yang menjadi korban berhak mendapatkan bantuan hukum dan bantuan lainnya.

Undang-Undang Nomor 23 Tahun 2002 tentang Perlindungan Anak memiliki 4 hak dasar, yaitu: 1. Hak hidup 2. Hak tumbuh kembang 3. Hak partisipasi 4. Hak perlindungan Kemudian bagaimana anak selama tidak diberikan nafkah oleh ayahnya, apakah anak tetap dapat memperoleh haknya ataukah tidak. Bagaimana nafkah madliyah anak pasca perceraian ditinjau dari aspek perlindungan hak anak menurut Undang-Undang Nomor 23 Tahun 2002 tentang Perlindungan anak? Menurut analisis peneliti sebagaimana disebutkan pada pasal 26 ayat 1 Undang-Undang Nomor 23 Tahun 2002 bahwa: orang tua berkewajiban dan bertanggung jawab untuk mengasuh, memelihara, mendidik, dan melindungi anak. Berdasarkan pasal tersebut artinya bahwa anak berhak untuk memperoleh asuhan, pemeliharaan, pendidikan dan perlindungan dari orang tuanya. Karena hal itu sudah menjadi kewajiban dan tanggung jawab orang tua terhadap anak, tidak hanya dari ibu saja,

melainkan juga dari ayah. Selanjutnya dalam pasal 4 Undang-Undang Nomor 23 Tahun 2002, bahwa setiap anak berhak untuk dapat hidup, tumbuh, berkembang, dan berpartisipasi secara wajar sesuai dengan harkat dan martabat kemanusiaan. Jika anak selama tidak diberi nafkah oleh ayah, namun ia tetap dapat tumbuh dan berkembang dengan memperoleh nafkah dari ibu saja, maka hak anak tersebut sudah terealisasikan. Kemudian pada pasal 9 ayat 1 menjelaskan bahwa: setiap anak berhak memperoleh pendidikan dan pengajaran dalam rangka pengembangan pribadinya dan tingkat kecerdasannya sesuai dengan minat dan bakatnya. Jika anak selama tidak dinafkahi oleh ayah, berakibat anak tidak dapat memperoleh pendidikan dan pengajaran yang seharusnya ia dapatkan, dalam hal ini anak tidak dapat bersekolah, maka hak anak untuk memperoleh pendidikan tidak terlaksana. Sedangkan ibu dalam keadaan tidak mampu bekerja seorang diri untuk dapat memenuhi kebutuhan- kebutuhan anak sehari-hari. Artinya bahwa anak dalam kondisi membutuhkan nafkah dari ayahnya.

Lebih lanjut pada pasal 13 Undang-Undang Nomor 23 Tahun 2002 menyebutkan bahwa: setiap anak selama dalam pengasuhan orang tua, wali, atau pihak lain mana pun yang bertanggung jawab atas pengasuhan, berhak mendapat perlindungan dari perlakuan: $a$. diskriminasi; b. eksploitasi, baik ekonomi maupun seksual; $c$. penelantaran; $d$. kekejaman, kekerasan, dan penganiayaan; e. ketidakadilan; dan $f$. perlakuan salah lainnya. ${ }^{35}$

Jika ayah yang pergi meninggalkan rumah, melalaikan anak dan tidak memberikan nafkah kepadanya. Dimana selama ayah tidak memberikan nafkah kepada anak berakibat anak tidak dapat memperoleh haknya dan mengalami kerugian baik moril maupun materil, maka hal tersebut dapat diartikan sebagai bentuk penelantaran. Karena ayah yang lari dari tanggung jawabnya terhadap keluarga terutama terhadap anak untuk merawat, mengasuh, mendidik dan melindungi anak. Apalagi jika ayah dalam kondisi mampu secara fisik dan keuangan untuk menafkahi namun sengaja melalaikan. Sehingga akibat dari ayah yang melalaikan tersebut, ibu harus memenuhi kebutuhan anak, membiayai

${ }^{35}$ Undang-undang Nomor 23 Tahun 2002, Lembaran Negara No. 109 Tahun 2002.

Jurisdictie: Jurnal Hukum dan Syariah Vol. 6 No. 1 Tahun 2015 
anak, merawat, mengasuh, mendidik dan melindungi anak seorang diri. Padahal dalam Undang-Undang Nomor 23 Tahun 2002 secara jelas menyebutkan bahwa orang tua memiliki kewajiban dan tanggung jawab terhadap anaknya. Artinya bahwa kewajiban dan tanggung jawab tersebut tidak hanya bagi ibu melainkan juga bagi ayah. Maka kewajiban seorang ayah terhadap anak yang telah dilalaikan dalam hal tersebut diatas, nafkah madliyah anak dapat dianggap sebagai hutang bagi ayah. Pemenuhan nafkah madliyah anak ini bertujuan untuk memberikan pemahaman serta pelajaran terhadap seorang ayah akan kewajiban dan tanggung jawabnya terhadap anak. Sehingga nantinya diharapkan seorang ayah sebagai kepala keluarga tidak lagi menelantarkan dan melalaikan keluarga, serta melaksanakan apa yang menjadi kewajiban dan tanggung jawabnya terhadap keluarga.

\section{Kesimpulan}

Kewajiban seorang ayah untuk memenuhi nafkah anak tidak menjadi hutang jika telah lewat masanya, namun nafkah tersebut dapat menjadi hutang jika ada keputusan hakim. Pembebanan ini dengan alasan: (a) ayah dalam kodisi mampu untuk bekerja, mampu dari segi fisik dan mampu dari segi keuangan; (b) ayah pergi meninggalkan rumah dan sengaja melalaikan anaknya; (c) anak dalam kondisi membutuhkan nafkah dari ayah untuk memenuhi kebutuhannya sehari-hari; (d) ibu dalam kondisi tidak mampu bekerja, seperti dalam keadaan sakit, atau memiliki cacat tubuh yang sehingga menghalangi pemberian nafkah kepada anaknya. Berdasarkan alasan di atas, keputusan Mahkamah Agung RI Nomor: 608/K/AG/2003 tidak bertentangan dengan hukum Islam. Setiap orang tua memiliki kewajiban untuk bertanggung jawab untuk mengasuh, memelihara, mendidik, dan melindungi anak. Oleh karena itu, seorang ayah yang dalam kenyataannya mampu dalam segi fisik maupun keuangan namun dengan sengaja melalaikan anaknya dan tidak memberikan nafkah, sehingga anak tidak dapat memperoleh haknya dan mengalami kerugian baik dari segi moril maupun materil, maka hal tersebut dapat dikatakan sebagai tindakan penelantaran sebagaimana diatur dalam Undang-Undang Nomor 23 tahun 2002 tentang Perlindungan Anak.

\section{Daftar Pustaka:}

Ali Qaimi. Menggapai Langit Masa Depan Anak. Translated by Muhammad Jawad Bafaqih. Bogor: Cahaya, 2002.

Amiruddin, and Zainal Asikin. Pengantar Metode Penelitian Hukum. Jakarta: RajaGrafindo Persada, 2012.

Aripin, Jaenal. Problematika Hukum Keluarga Islam Kontemporer. Jakarta: Prenada Media, 2004.

Azzam, Abdul Aziz Muhammd, and Abdul Wahhab Sayyed Hawwas. Fiqh Munakahat “Khitbah, Nafkah Dan Talak." Jakarta: Amzah, 2009.

Az-Zuhaili, Wahbah. Fiqh Islam Wa Adillatuhu. Translated by Abdul Hayyie alKattani. Vol. 10. Jakarta: Gema Insani Press, 2011.

Bagir, Muhammad. Fiqih Praktis II: Menurut Al-Quran, As-Sunnah, dan Pendapat Para Ulama. Bandung: Karisma, 2008.

Cholil, Mufidah. Psikologi Keluarga Islam Berwawasan Gender. Malang: UIN-Malang Press, 2013.

C.S.T. Kansil. Pengantar Ilmu Hukum Dan Tata Hukum Indonesia. Jakarta: Balai Pustaka, 1989.

Gultom, Maidin. Perlindungan Hukum Terhadap Anak dan Perempuan. Bandung: Refika Aditama, 2012. 
i, Muhammad bin Idris al-Syafi'. Ringkasan Kitab Al-Umm Buku II. Translated by Muhammad Yasir Abd. Muthalib. Jakarta: Pustaka Azzam, 2007.

Mardani. Hukum Perkawinan Islam Di Dunia Islam Modern. Yogyakarta: Graha Ilmu, 2011.

Marzuki, Peter Mahmud. Penelitian Hukum. Jakarta: Kencana, 2010.

Sabiq, Sayyid. Fikih Sunnah. Translated by Moh. Thalib. Vol. 6. Bandung: Alma'arif, 1987.

Soekanto, Soerjono, and Sri Mamudji. Penelitian Hukum Normatif: Suatu Tinjauan Singkat. Jakarta: RajaGrafindo Persada, 2006.

Sudarsono. Kamus Hukum. Jakarta: Rineka Cipta, 1992.

Putusan Mahkamah Agung RI Nomor 608/K/AG/2003

Undang-Undang No. 23 Tahun 2002 tentang Perlindungan Anak Lembaran Negara No. 109 Tahun 2002

Undang-Undang Nomor 1 Tahun 1974 tetang Perkawinan Lembaran Negara No. 1 Tahun 1974

Kompilasi Hukum Islam yang disebarluaskan melalui Instruksi Presiden No. 1 Tahun 1991 